\title{
Changes in Soluble-N in Forest and Pasture Soils after Repeated Applications of Tannins and Related Phenolic Compounds
}

\author{
Jonathan J. Halvorson, ${ }^{1}$ Javier M. Gonzalez, ${ }^{1}$ and Ann E. Hagerman ${ }^{2}$ \\ ${ }^{1}$ USDA-ARS Appalachian Farming Systems Research Center, 1224 Airport Road, Beaver, WV 25813-9423, USA \\ ${ }^{2}$ Department of Chemistry and Biochemistry, Miami University, 160 Hughes Laboratories, 701 East High Street, \\ Oxford, OH 45056, USA
}

Correspondence should be addressed to Jonathan J. Halvorson, jonathan.halvorson@ars.usda.gov

Received 15 September 2011; Accepted 7 December 2011

Academic Editor: Dexter B. Watts

Copyright (C) 2012 Jonathan J. Halvorson et al. This is an open access article distributed under the Creative Commons Attribution License, which permits unrestricted use, distribution, and reproduction in any medium, provided the original work is properly cited.

Tannins (produced by plants) can reduce the solubility of soil-N. However, comparisons of tannins to related non-tannins on different land uses are limited. We extracted soluble- $\mathrm{N}$ from forest and pasture soils $(0-5 \mathrm{~cm})$ with repeated applications of water (Control) or solutions containing procyanidin from sorghum, catechin, tannic acid, $\beta$-1,2,3,4,6-penta-O-galloyl-D-glucose (PGG), gallic acid, or methyl gallate $\left(10 \mathrm{mg} \mathrm{g}^{-1}\right.$ soil $)$. After eight treatments, samples were rinsed with cool water $\left(23^{\circ} \mathrm{C}\right)$ and incubated in hot water $\left(16 \mathrm{hrs}, 80^{\circ} \mathrm{C}\right)$. After each step, the quantity of soluble-N and extraction efficiency compared to the Control was determined. Tannins produced the greatest reductions of soluble- $\mathrm{N}$ with stronger effects on pasture soil. Little soluble- $\mathrm{N}$ was extracted with cool water but hot water released large amounts in patterns influenced by the previous treatments. The results of this study indicate hydrolyzable tannins like PGG reduce the solubility of labile soil-N more than condensed tannins like sorghum procyanidin (SOR) and suggest tannin effects will vary with land management. Because they rapidly reduce solubility of soil-N and can also affect soil microorganisms, tannins may have a role in managing nitrogen availability and retention in agricultural soils.

\section{Introduction}

Tannins are reactive secondary metabolites produced by plants that affect important biological, chemical, and physical processes in soil and couple primary productivity to biogeochemical cycles [1-4]. Tannin effects on decomposition and nitrogen availability in soil have been a subject of research for more than fifty years $[5,6]$. However, development of strategies for use of tannins as soil management tools has lagged, in part because few studies have specifically related them to improving plant productivity or soil fertility. Early tannin research was conducted on temperate agricultural soils [7-9], while recent work has concentrated more on their role in forest ecosystems [10-12] and tropical soils [1315]. These studies, however, have tended to emphasize the impacts of tannins on microbially mediated processes rather than on the more immediate abiotic interactions between tannins and soil and have made little attempt to frame their findings into the context of landscape effects.
Tannins are believed to affect the nitrogen cycle through several direct and indirect mechanisms that reduce rates of net mineralization or nitrification. Some tannins are directly toxic to plants or microorganisms $[16,17]$ but their effects vary with particular tannin chemistry or among taxonomic groups [18]. Some tannins or related phenolic compounds are used by soil microorganisms as substrates increasing microbial demand for nitrogen and immobilization in microbial biomass $[2,12,19]$. Tannins can also reduce rates of mineralization or decomposition by affecting the activity of enzymes $[20,21]$ or by forming complexes with other proteins or organic nitrogen compounds via reversible noncovalent processes such as hydrogen bonding and hydrophobic interactions (cf. $[2,22,23])$. The availability of the nitrogen sequestered in tannin-protein complexes varies among species of plants, taxa of microorganisms, or even among strains of mycorrhizae [11,24-28]. Tannins and related phenolics may also affect soil-N through interactions with inorganic soil fractions $[3,23,29]$. For example, tannin-related 
phenolic compounds can interact with nitrite, produced during nitrification, to form more recalcitrant organic forms in a process termed nitrosation [30-32].

Our earlier studies revealed some tannins were rapidly sorbed by soil and reduced the solubility of labile soil-N $[33,34]$. Significant amounts of retained tannin-C remained in soil even after repeated rinses with hot water [33]. A single application of a gallotannin $(\beta-1,2,3,4,6$-penta- $O$-galloyl-Dglucose) produced a persistent reduction in the solubility of organic-N not observed with gallic acid, its simple monomeric constituent, suggesting the rapid formation of stable complexes with soil [33]. Tannic acid also influenced the recovery and composition of Bradford-reactive soil protein, associated with glomalin, produced by arbuscular mycorrhizae [35]. These observations suggested plant tannins are capable of affecting critical soil ecosystem processes such as formation of soil organic matter and rates of nutrient cycles and thus may have a role in managing nitrogen availability and retention in soil.

This report is a portion of a two-part study designed to expand the body of basic information about the effects of tannins and related non-tannin phenolics on soil organic matter and nutrient cycling. In part 1 , we reported patterns of sorption of phenolic-C and showed Appalachian forest and pasture soils had a high affinity and a fixed capacity for tannins while related phenolic compounds were retained less [34]. This work summarizes the effects of repeated applications of chemically well-defined hydrolyzable and condensed tannins (polymers) and related non-tannin phenolic substances (monomers) on the solubility of soil-N. We compared surface soil from pasture to soil from the surrounding woodlands to gain insight into the magnitude of change associated with conversion from woodlands to silvopasture and assessed their potential significance on a landscape basis. Our ultimate goal is to gather and develop information needed to devise new management strategies that use the phenolic compounds added by plant residues, leachates, livestock manure or, from intentional amendments, to achieve desired agronomic or environmental goals.

\section{Materials and Methods}

2.1. Sample Collection and Preparation. Surface soil $(0-5 \mathrm{~cm})$ was collected from four farm units in Southern West Virginia, each with areas in forest (mixed deciduous or pine) and pasture use as described in greater detail by Halvorson and Gonzalez [36] and Halvorson et al. [34]. Each sample consisted of a composite of 10 soil cores $(6.35 \mathrm{~cm}$ in diameter) collected along transects. In the lab, composite samples were sieved $(2 \mathrm{~mm})$, dried at $55^{\circ} \mathrm{C}$, and stored until further analysis.

2.2. Soil Properties. Bulk density (BD) was determined gravimetrically from intact soil cores [36]. Soil chemical properties were determined for each composite sample (Table 1). Soil $\mathrm{pH}$ and electrical conductance (EC) were measured by electrode ( $1: 1$ soil : water). Total inorganic-N (TIN) was estimated as the sum of water extractable inorganic-N plus $\mathrm{KCl}$ extractable- $\mathrm{N}$ remaining in soil after the first extraction reported in previous work [33]. Total soil-C content was determined by dry combustion [37] with a FlashEA 1112 NC Analyzer (CE Elantech, Lakewood, NJ). The texture of the soil samples was determined by hydrometer (Midwest labs, Omaha, NE, http://www.midwestlabs.com/). Cation exchange capacity (CEC) was measured at the inherent soil $\mathrm{pH}$ by exchange with cobalt hexamine trichloride [38-40].

\subsection{Effects of Test Compounds on Extraction of Soil-N. As} part of a larger study [34], soluble-N extracted from soil was determined by difference after each of eight repeated applications of aqueous treatment solutions followed by a sequential extraction with $\operatorname{cool}\left(23^{\circ} \mathrm{C}\right)$ and hot $\left(80^{\circ} \mathrm{C}\right)$ water $[41$, 42].

2.3.1. Test Compounds. Soil samples were treated with deionized water (Control) or with solutions containing model tannins or non-tannin phenolic compounds (organic acids and flavonoids), selected to represent a range of phenolic compounds of varying complexity present in the plantsoil continuum [43]. Our representative condensed tannin was a polymeric flavonoid-based procyanidin isolated from sorghum grain [Sorghum bicolor (L.) Moench] (SOR) [44]. We also evaluated tannic acid (TA), a common but imprecisely defined mixture of galloyl esters, and $\beta-1,2,3,4,6-$ penta-O-galloyl-D-glucose (PGG), a well-defined gallotannin purified from the tannic acid. Non-tannin phenolics included the flavonoid catechin (CAT), the phenolic acid gallic acid (GA), and its ester, methyl gallate, (MG) (Figure 1, Table 2).

2.3.2. Procedure. Samples of soil $(2.5 \mathrm{~g})$ were weighed into Oak Ridge centrifuge tubes and treated with $25 \mathrm{~mL}$ of deionized water (Control) or with $25 \mathrm{~mL}$ of test solution to yield a final amendment of $10 \mathrm{mg}$ test compound $\mathrm{g}^{-1}$ soil. After reciprocal shaking at $200 \mathrm{rpm}$ for 1 hour at room temperature, samples were centrifuged for $3 \mathrm{~min}$ at $11,952 \mathrm{~g}$ and decanted. Supernatants were analyzed for soluble-N with a Shimadzu TOC-VCPN analyzer equipped with a TNM-1 module (Shimadzu Scientific Instruments, Columbia, MD). The treatment application step was repeated seven more times by adding an additional $25 \mathrm{~mL}$ of Control or treatment solution to the soil pellet, shaking, and extracting as above. After the final treatment, all samples were extracted with $25 \mathrm{~mL}$ of cool $\left(23^{\circ} \mathrm{C}\right)$ water and assayed again. Finally, more water $(25 \mathrm{~mL})$ was added to soil samples, which were then vortexed, incubated overnight in a hot water bath $(16 \mathrm{hrs}$, $80^{\circ} \mathrm{C}$ ), and assayed for soluble- $\mathrm{N}$ as before.

Data were corrected to account for any nitrogen added from the treatments, or carryover from the previous treatment step. Treatment effects were determined for absolute values $\left(\mathrm{mg} \mathrm{kg}^{-1}\right.$ soil) but the amount of net soluble-N extracted by treatment solutions was also expressed relative to the Control and used to determine if treatments decreased (net Treatment $<$ net Control) or increased (net Treatment > net Control) extraction of soluble-N 
TABLE 1: Selected soil properties adapted from Halvorson et al. [34]. Mean (SEM), $n=4$.

\begin{tabular}{|c|c|c|c|c|c|c|c|c|c|c|}
\hline Land use & $\mathrm{BD}^{\dagger}$ & $\mathrm{pH}(1: 1)$ & $\begin{array}{c}\mathrm{EC} \\
(\mu \mathrm{S} \mathrm{cm} \\
\left.\mathrm{soil}^{-1}\right)\end{array}$ & $\begin{array}{c}\mathrm{TIN}^{\ddagger} \\
(\mathrm{mg} \mathrm{N} \mathrm{kg} \\
\left.\text { soil }^{-1}\right)\end{array}$ & $\begin{array}{l}\text { Total C } \\
(\mathrm{mg} \mathrm{C} \mathrm{g} \\
\left.\text { soill }^{-1}\right)\end{array}$ & $\begin{array}{c}\text { Total N } \\
(\mathrm{mg} \mathrm{N} \mathrm{g} \\
\left.\text { soill }^{-1}\right)\end{array}$ & $\begin{array}{c}\text { CEC } \\
\left(\mathrm{cmolc} \mathrm{kg} \text { soil }^{-1}\right)\end{array}$ & $\begin{array}{c}\text { Sand } \\
\%\end{array}$ & $\begin{array}{c}\text { Silt } \\
\%\end{array}$ & $\begin{array}{c}\text { Clay } \\
\%\end{array}$ \\
\hline Forest & $0.95(0.03)$ & $4.47(0.26)$ & $103(13)$ & $17.3(3.4)$ & $56.0(3.5)$ & $4.0(0.2)$ & $9.8(1.9)$ & $73.0(3.1)$ & $20.5(2.2)$ & $6.5(1.0)$ \\
\hline Pasture & $1.14(0.09)$ & $5.27(0.08)$ & $151(14)$ & $26.5(4.4)$ & $42.9(2.4)$ & $4.5(0.4)$ & $10.1(1.0)$ & $69.0(6.0)$ & $25.0(5.3)$ & $6.0(0.8)$ \\
\hline
\end{tabular}

${ }^{\dagger}$ Bulk density (BD) for the study was determined gravimetrically.

${ }^{\ddagger}$ Total inorganic-N (TIN) was estimated as the sum of water extractable inorganic-N plus KCl extractable-N remaining in soil [33].<smiles>Oc1cc(O)c2c(c1)O[C@H](c1ccc(O)c(O)c1)[C@H](O)C2</smiles>

(a) (+)-Catechin<smiles>O=C(O)c1cc(O)c(O)c(O)c1</smiles>

(b) Gallic acid<smiles>COC(=O)c1cc(O)c(O)c(O)c1</smiles>

(c) Methyl gallate<smiles>Oc1cc(O)c2c(c1)O[C@H](c1ccc(O)c(O)c1)[C@H](O)[C@H]2c1c(O)cc(O)c2c1O[C@H](c1ccc(O)c(O)c1)[C@H](O)[C@H]2c1c(O)cc(O)c2c1O[C@H](c1ccc(O)c(O)c1)[C@H](O)C2</smiles>

(d) Sorghum procyanidin<smiles>COCC1OC(OC)C(OC)C2OC1C2OC</smiles>

(e) $\beta$-1, 2, 3, 4 , 6-penta- $O$-galloyl-D-glucose<smiles>COCC1OC2(OOCO)OC1C(OO)C(OOC)C2OOC</smiles>

(f) Tannic acid $\mathrm{G}=$ gallic acid ester

Figure 1: Chemical structures for (a) (+)-catechin (CAT), (b) gallic acid (GA), (c) methyl gallate (MG), (d) sorghum procyanidin (SOR), (e) $\beta$-1,2,3,4,6-penta-o-galloyl-d-glucose (PGG), and (f) tannic acid (TA). The structure shown for tannic acid is a representative molecule for tannic acid, an imprecisely defined mixture of galloyl esters [44]. Figure redrawn from [34]. 


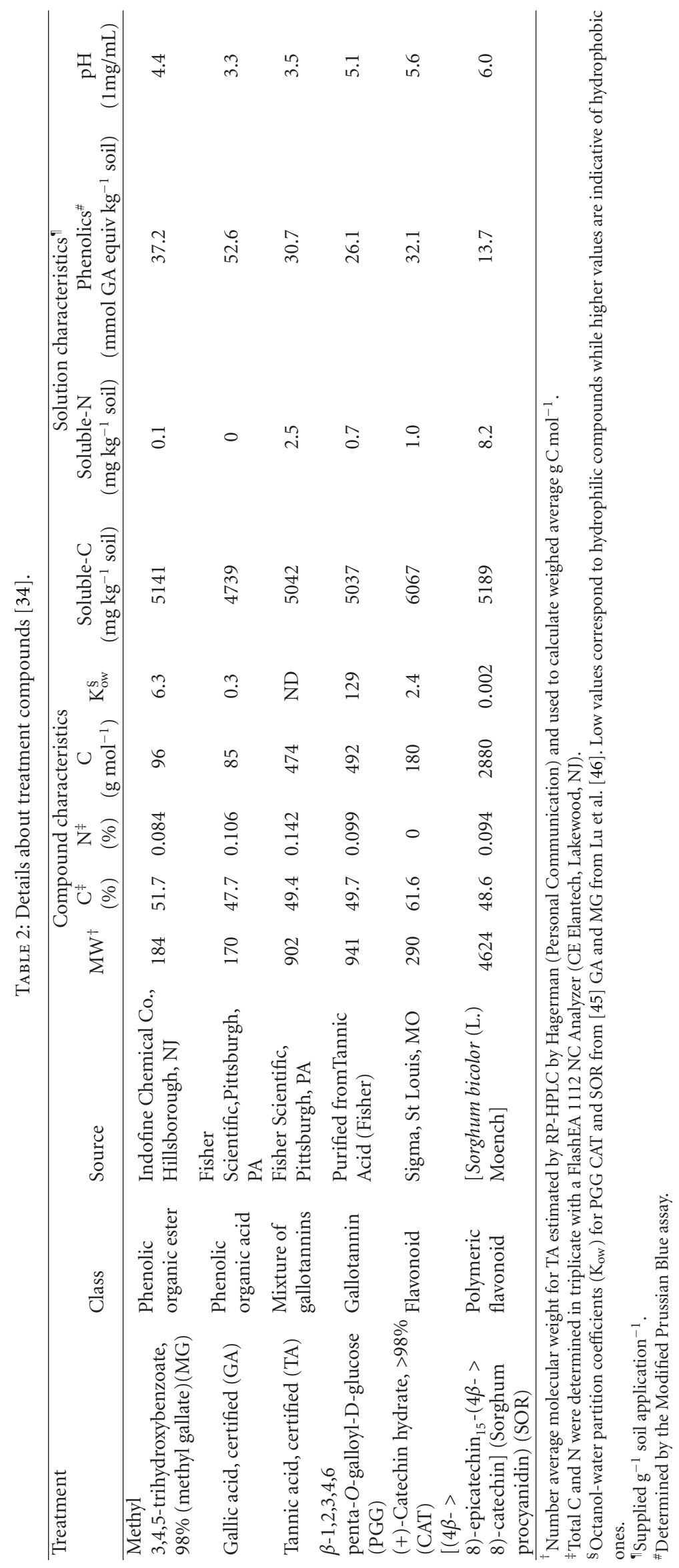


from soil. We determined percentage change in soluble- $\mathrm{N}$ attributable to treatments, $\Delta$ Sol-N, as

$$
\Delta \text { Sol-N }=100 * \frac{\left(\text { Sol- } \mathrm{N}_{\text {trt }}-\text { Sol- }-\mathrm{N}_{\text {control }}\right)}{\text { Sol- }_{\text {control }}},
$$

where Sol- $\mathrm{N}_{\text {trt }}$ and Sol- $\mathrm{N}_{\text {control }}$ indicate the amount of net soluble- $\mathrm{N}$ extracted from soil samples treated with phenolic compounds or water alone, respectively.

2.4. Statistical Analysis. Significant effects of test compounds and land use were identified by analysis of variance (ANOVA) with SAS 9.1 and PROC MIXED using a model that accounted for both fixed (land use, treatment) and random (sample location) effects [47, 48]. We used the KR (KenwardRoger) option to calculate degrees of freedom and selected covariance structures to minimize Akaike's Information Criterion. Assumptions of data normality were evaluated and appropriate data transformations identified with SAS/ ASSIST. We assumed a value of $5 \%$ as the minimum criterion for significance. Significant main effects were separated by pairwise comparisons among means, adjusted by the TukeyKramer method. The SLICE option in PROC MIXED was used to test significant Treatment $\times$ Use interaction. Significant deviation of $\Delta$ Sol-N from zero, indicative of a meaningful change in soluble- $\mathrm{N}$ due to the treatment, was determined by the LSMEANS statement in PROC MIXED. Values indicated in text and graphs are the arithmetic mean, \pm the standard error of the mean, expressed on air-dry soil basis.

\section{Results}

3.1. General Patterns. Multiple applications of phenolic solutions produced overall extraction pattern for soluble$\mathrm{N}$ shown in Figure 2. The first of the eight cycles had the greatest effect, extracting $50-60 \%$ of the cumulative total amount, while each of the seven subsequent applications removed incrementally less $\mathrm{N}$. The rinse with cool water after the treatment cycles extracted little additional soluble-N but the final incubation in hot water released a relatively large pulse of soluble- $\mathrm{N}$ from all treatments and the control. The distinct patterns of $\Delta$ Sol-N, established with the first treatment application, generally varied little with subsequent phenolic treatments or cool water rinse but showed some differences between forest and pasture soils (Figures $3(\mathrm{a})$ and $3(\mathrm{~b})$ ).

3.2. Treatment with Phenolic Compounds. The amount of soluble- $\mathrm{N}$ extracted by the first treatment cycle varied with simple main effects of Treatment and Use. Soluble-N was comparable for most treatments with amounts from samples treated with MG slightly greater than the Control (Table 3 ). In contrast, both TA and PGG reduced amounts of soluble$\mathrm{N}$. Pasture soil produced more soluble-N than forest soil. Extraction efficiency of treatments compared to the water Control, $\Delta$ Sol-N, varied as a Treatment $\times$ Use interaction. Treatment with MG significantly increased the amount of soluble-N from forest soil by about $19 \%$ compared to $9 \%$ for pasture soil (Figure 4). Treatment with CAT did not affect

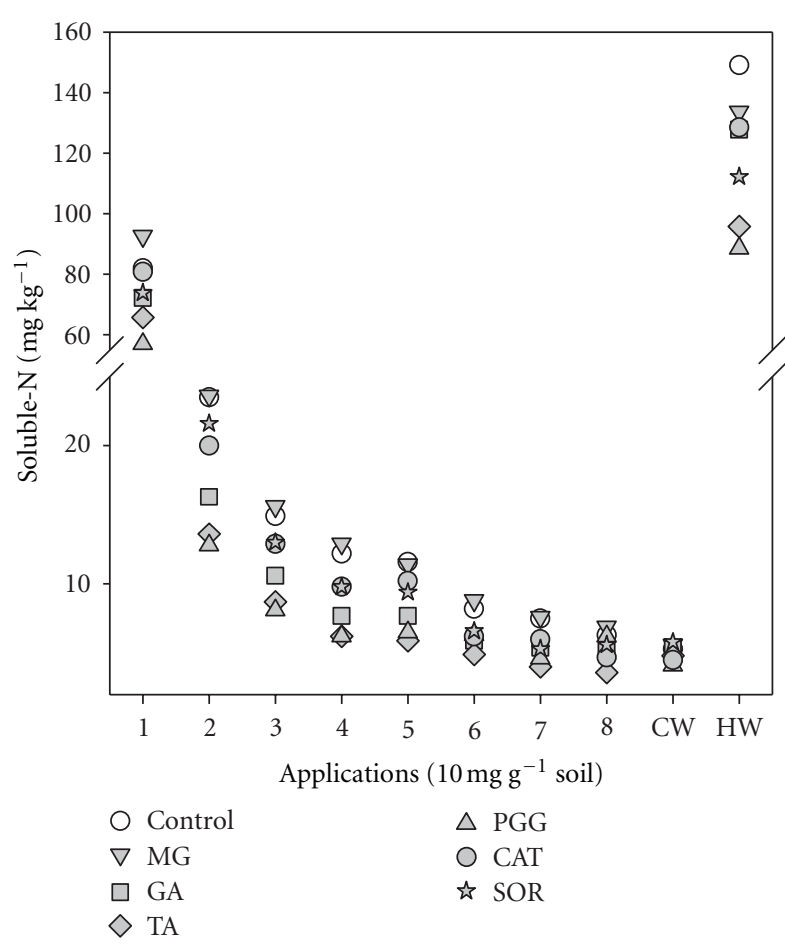

FIgure 2: Soluble-N extracted from $0-5 \mathrm{~cm}$ soil with eight treatment cycles of water (Control) or treatment solutions $\left(10 \mathrm{mg} \mathrm{g}^{-1}\right.$ soil) followed by extractions with cool (CW) and hot (HW) water. Values are the mean of 4 farms $\times 2$ uses (forest and pasture), $n=8$. Treatment abbreviations are defined in Figure 1.

soluble-N from pasture or forest soil. Gallic acid produced no effect on forest soil, but reduced soluble- $\mathrm{N}$ from pasture soil by $19 \%$. Soluble-N was reduced from both soil types by SOR, TA, and PGG, but decreases were stronger in pasture soil. Greatest reductions resulted from the PGG treatment, which lowered soluble-N from forest and pasture by 24 and $34 \%$, respectively.

Patterns established with the first treatment cycle persisted throughout the seven subsequent applications of phenolics and thus cumulative extractions, after all eight treatment cycles, varied with main effects of Treatment and Use (Table 3 ). While MG slightly increased soluble-N, amounts were significantly reduced by GA, TA, and PGG treatments. Pasture soil yielded more soluble- $\mathrm{N}$ than forest soil. Cumulative treatment $\Delta$ Sol-N varied as a Treatment $\times$ Use interaction. Eight treatment cycles with MG extracted $13 \%$ more soluble- $\mathrm{N}$ from forest soil than water alone but had little effect on pasture soil. By contrast, treatment with CAT reduced soluble-N by about $9 \%$ for both soils. Soluble-N was also reduced by the other phenolic compounds but treatment effects were discernibly stronger for pasture soil. Greatest reductions, with PGG, resulted in 28 and $40 \%$ less soluble-N, than the water control, from forest and pasture, respectively.

3.3. Cool and Hot Water Extractions. Only small amounts, $5.1 \pm 0.2 \mathrm{mg} \mathrm{kg}^{-1}$, of soluble- $\mathrm{N}$, were extracted by cool water, after the final treatment cycle, limiting the interpretive value 


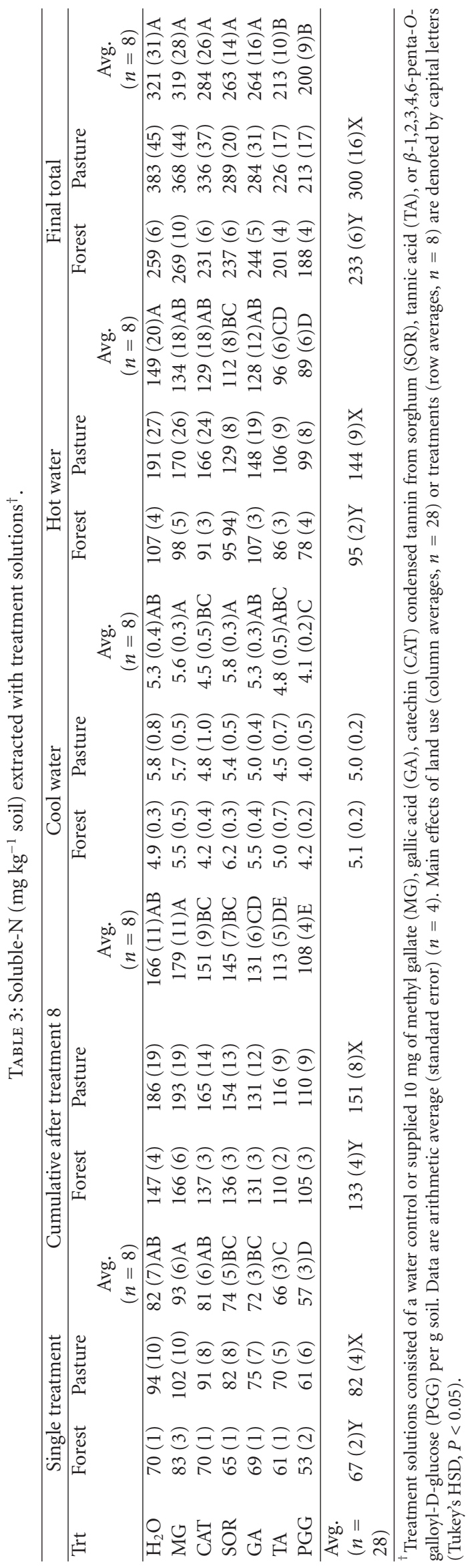




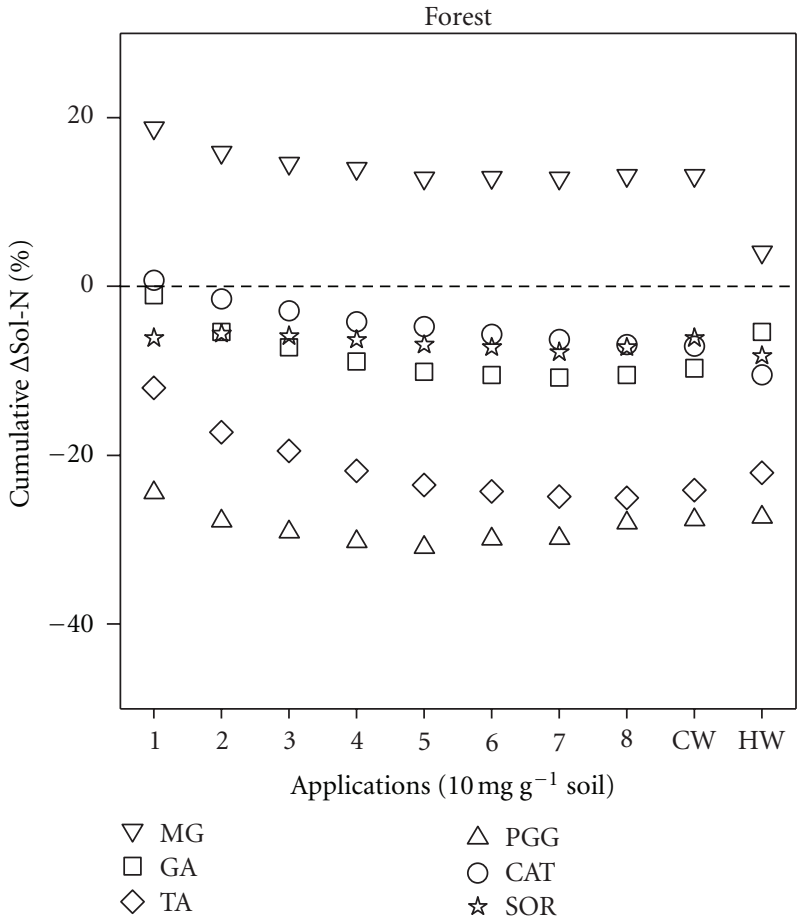

(a)

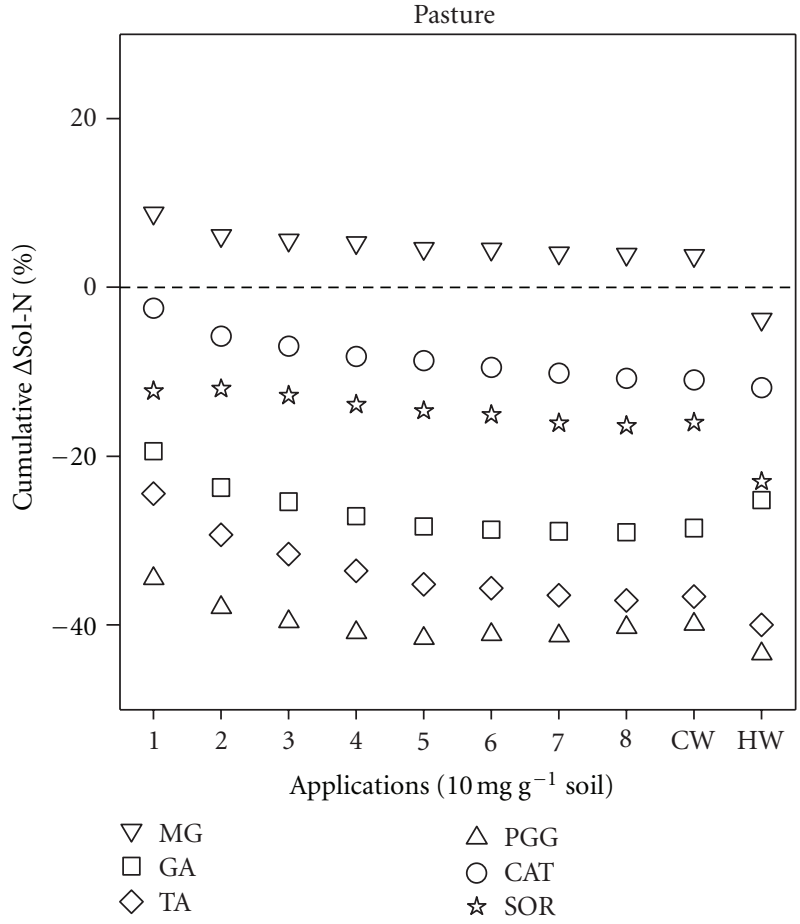

(b)

Figure 3: Percent change in soluble-N extractions attributable to treatments, $\Delta$ Sol-N for (a) forest and (b) pasture soils calculated with (1) $(n=4)$. Treatment abbreviations are defined in Figure 1.

of intertreatment $\Delta$ Sol-N comparisons (Table 3). Variation among treatment effects was less than $2 \mathrm{mg} \mathrm{kg}^{-1}$ soil but samples treated with PGG yielded less cool water soluble-N than others.

In contrast, hot water extracted large amounts of soluble$\mathrm{N}$ that varied with simple main effects of Treatment and Use (Table 3). The greatest amount of soluble-N, extracted from the Control treatment, was comparable to the amount extracted by the preceding eight treatment cycles (Table 3 ). Significantly less soluble-N was extracted with hot water from TA- and PGG-treated samples than other treatments. Pasture produced about 50\% more soluble- $\mathrm{N}$ than forest soil.

Hot water $\Delta$ Sol-N varied as an interaction between Treatment and Use (Figure 5). Gallic acid had no effect on hot water extractions from forest soil, compared to the Control, but reduced soluble-N from pasture samples by $22 \%$. Previous treatments with MG and CAT reduced soluble-N similarly from forest and pasture soils, by 10 and $14 \%$, respectively. Reductions in soluble- $\mathrm{N}$, observed for samples treated with SOR, TA, or PGG, were greater in pasture than forest soil. Hot water soluble-N was reduced from samples previously treated with $\mathrm{PGG}$, by $27 \%$ for forest soil and by $47 \%$ for pasture.

3.4. Cumulative Extraction of Soluble-N. Final cumulative soluble-N extracted by eight treatment cycles and subsequent cool and hot rinses differed by Treatment and Use (Table 3). Treatment effects segregated into two groups with less total soluble-N extracted from soils treated with TA or PGG.
Pasture soil yielded an average of $300 \mathrm{mg} \mathrm{kg}^{-1}$ soluble-N or about $29 \%$ more than forest soil.

Final cumulative $\Delta$ Sol-N varied as an interaction between Treatment and Use (Figure 6). In both forest and pasture soils, $\Delta$ Sol-N was highest from samples treated with MG and lowest from samples treated with TA or PGG. The repeated treatments with MG did not significantly influence cumulative extraction of soluble- $\mathrm{N}$ from forest or pasture soil. Forest soil was also unaffected by GA but soluble-N was reduced from pasture soil by $25 \%$ (nearly $100 \mathrm{mg} \mathrm{kg}^{-1}$ ). Treatments with CAT reduced soluble-N similarly from both land uses by an average of $11 \%$ (about $37 \mathrm{mg} \mathrm{kg} \mathrm{kg}^{-1}$ ). Tannins produced the greatest reductions of soluble- $\mathrm{N}$ with significantly stronger effects on pasture soil. The condensed tannin, SOR, reduced cumulative extractions of soluble-N from forest and pasture soils by 8 and 23\%, respectively, (21 and $93 \mathrm{mg} \mathrm{kg}^{-1}$ ). Tannic acid, reduced soluble-N from forest soil by $22 \%\left(58 \mathrm{mg} \mathrm{kg}^{-1}\right)$ and by $40 \%\left(156 \mathrm{mg} \mathrm{kg}^{-1}\right)$ from pasture soil. The hydrolyzable tannin, PGG, produced greatest reductions, 27 and $43 \%$ from forest and pasture soils, respectively, (71 and $176 \mathrm{mg} \mathrm{kg}^{-1}$ ).

\section{Discussion}

When expressed on a landscape basis, the size of the pool of soil $\mathrm{N}$ affected by tannins and other phenolic compounds appears significant. Water alone (Control) extracted the equivalent of 33 and $54 \mathrm{~kg}$ of soluble- $\mathrm{N} \mathrm{ha}^{-1}$ from $0-5 \mathrm{~cm}$ of forest and pasture soils with the first treatment cycle 


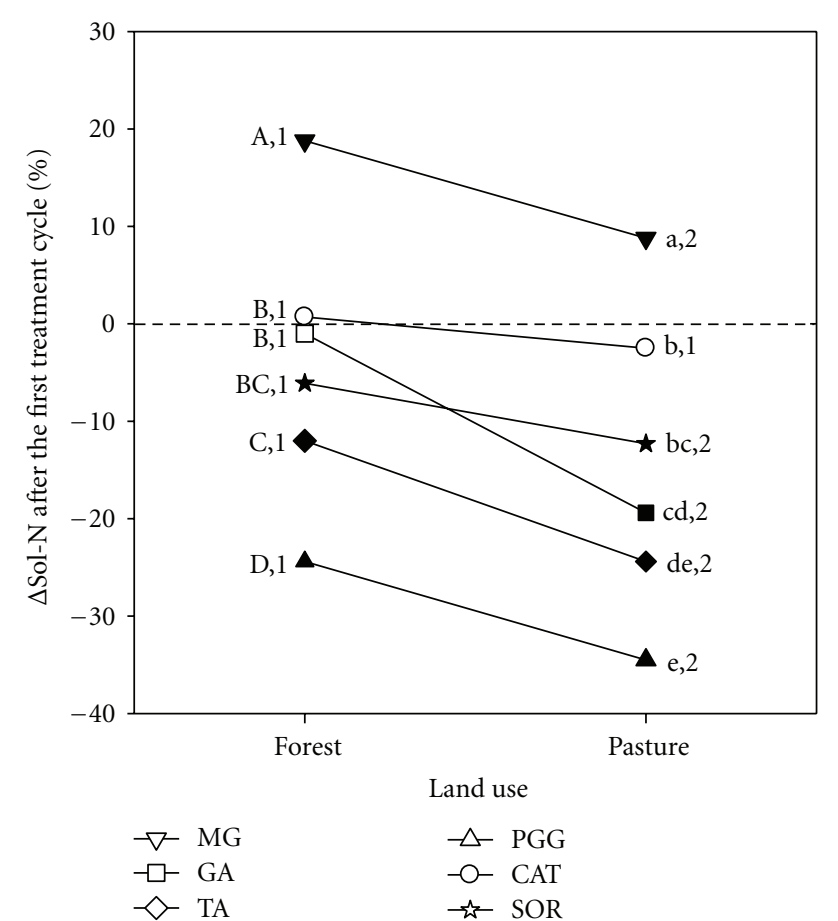

FIgURE 4: Treatment $\times$ Use interactions for $\Delta$ Sol-N after the first application of treatment solutions $\left(10 \mathrm{mg} \mathrm{g}^{-1}\right.$ soil). Within each land use, letters denote differences among treatments. Differences between uses are denoted by numbers. Filled symbols denote significant deviations from the control. Treatment abbreviations are defined in Figure 1.

(Tables 1 and 3). Compared against these baseline values, the first treatment with MG increased losses of soluble-N from forest and pasture soils by $5-6 \mathrm{~kg} \mathrm{Nha}^{-1}$ while PGG conserved 8 and $19 \mathrm{~kg} \mathrm{Nha}^{-1}$ in forest and pasture samples, respectively. These reductions of soluble- $\mathrm{N}$ were strongly correlated with the amount of phenolic treatment- $\mathrm{C}$ sorbed by the soil [34] (Figure 7).

Incremental extractions of nitrogen after eight successive treatment applications were small suggesting a majority of the most labile pool of soil-N had been removed (Figure 2). The difference between Control extractions, equivalent to 70 and $106 \mathrm{~kg} \mathrm{ha}^{-1}$ from forest and pasture soils, and treatment extractions infer the magnitude of the soil-N pool most responsive to the phenolic inputs. These suggest the eight treatments with MG mobilized an additional 19 and $7 \mathrm{mg}$ $\mathrm{N} \mathrm{kg}^{-1}$ forest or pasture soil, compared to water, or 9 and $4 \mathrm{~kg} \mathrm{~N} \mathrm{ha}^{-1}$. Conversely, PGG reduced the solubility of labile soil-N by 41 and $76 \mathrm{mg} \mathrm{kg}^{-1}$ in forest and pasture soils, respectively, equivalent to retention of 21 and $43 \mathrm{~kg} \mathrm{~N} \mathrm{ha}^{-1}$.

Negligible extractions of soluble- $\mathrm{N}$ with cool water, exhibiting only small differences among treatments, were unexpected (Table 3 ). We had, instead, anticipated relatively large releases of soluble- $\mathrm{N}$ from samples that had previously retained $\mathrm{N}$ once the treatments were omitted.

In contrast to cool water, hot water released large amounts of soluble- $\mathrm{N}$, accounting for between 40 and 50\% of the cumulative extraction, suggesting it originated from a

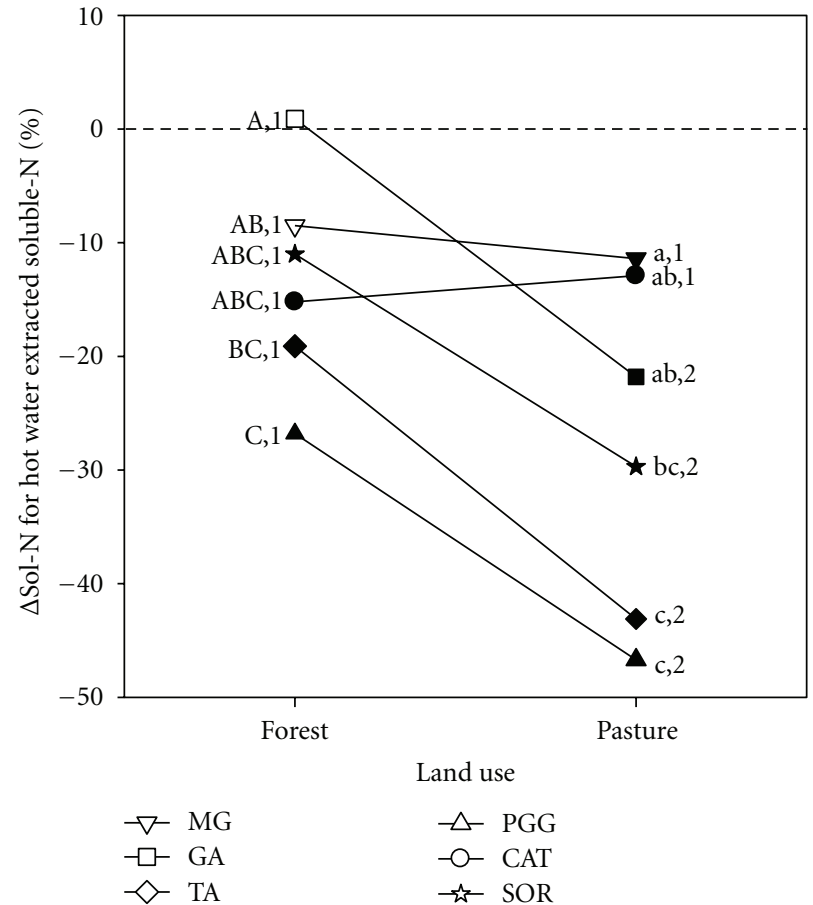

FIGURE 5: Treatment $\times$ Use interactions for $\Delta$ Sol-N calculated for hot water extractions (not cumulative). Within each land use, letters denote differences among treatments. Differences between uses are denoted by numbers. Filled symbols denote significant deviations from the control. Treatment abbreviations are defined in Figure 1.

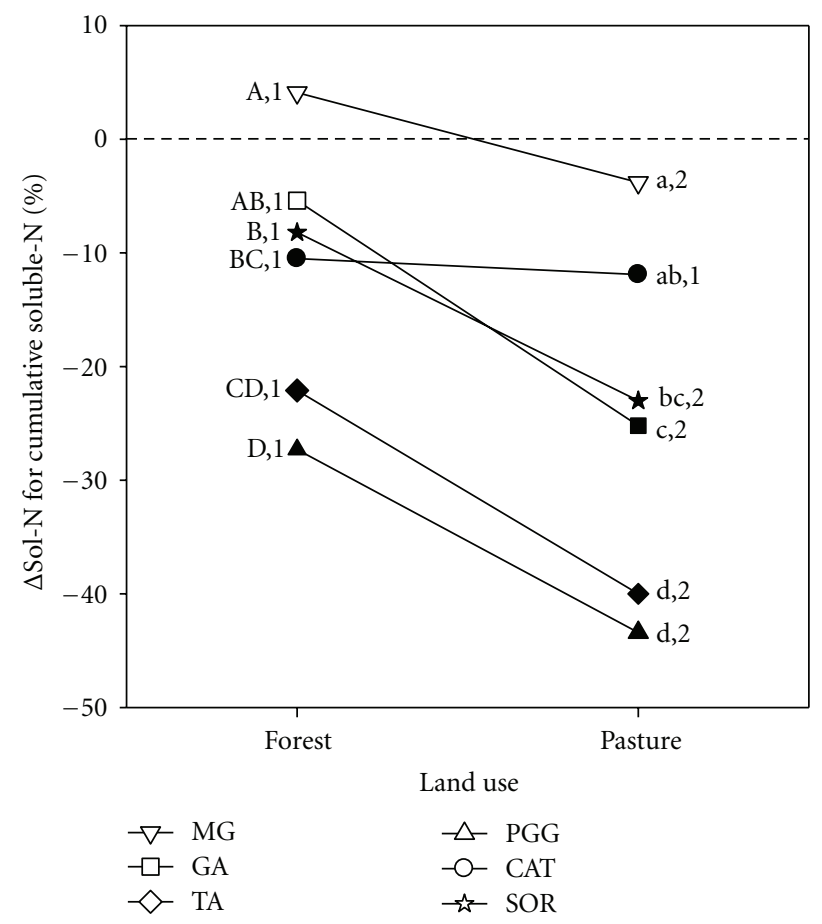

FIgURE 6: Treatment $\times$ Use interactions for $\Delta$ Sol-N calculated for cumulative extractions. Within each land use, letters denote differences among treatments. Differences between uses are denoted by numbers. Filled symbols denote significant deviations from the control. Treatment abbreviations are defined in Figure 1. 


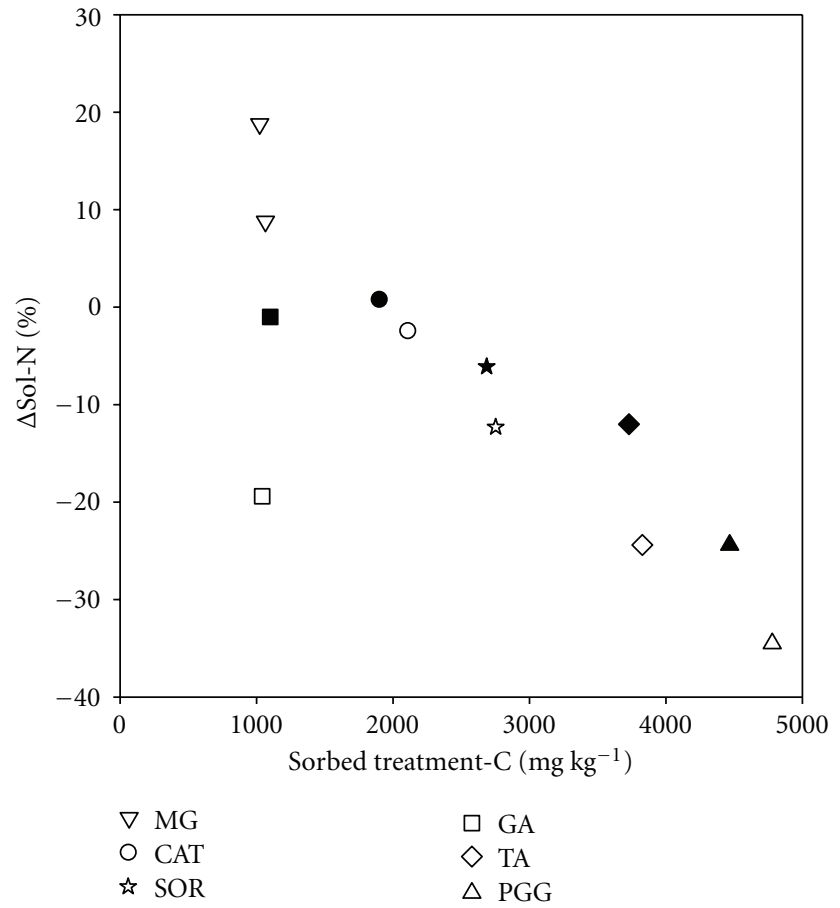

FIGURE 7: Relationship between $\Delta$ Sol-N and sorbed treatment-C after the first application of treatments. Data from forest and pasture soils are denoted by filled and open symbols, respectively. Values for treatment-C are from [34]. Treatment abbreviations are defined in Figure 1.

different pool of soil organic matter. The hot water-soluble pool from forest soil, $51 \mathrm{~kg} \mathrm{Nha}^{-1}$, was less than half that from pasture soil, $110 \mathrm{~kg} \mathrm{Nha}^{-1}$. Hot water-extractable soil$\mathrm{N}$ is thought to be primarily composed of unspecified forms of organic-N, particularly amino- $\mathrm{N}$ and amides, associated with soil microbial biomass and organic matter, with the remainder consisting of $\mathrm{NH}_{4}-\mathrm{N}$, generated by hydrolysis of heat-labile organic $\mathrm{N}[41,42,49]$. In a previous experiment, Halvorson et al. [33] found organic-N comprised more than $80 \%$ of soluble- $\mathrm{N}$ extracted by hot water after a single treatment with GA, TA or PGG.

The patterns of treatment effects observed for hot water soluble-N, along with those observed for the preceding extractions, suggest phenolic compounds, like MG, may simply affect the efficacy of the extraction process while others including the tannins and CAT somehow increase the ability for organic- $\mathrm{N}$ to resist hydrolysis or physically restrain it in the soil matrix. While eight treatments with MG increased soluble- $\mathrm{N}$ in supernatants by an average $7 \mathrm{~kg} \mathrm{Nha}^{-1}$ (Table 3), hot water soluble-N from samples treated with MG was reduced by $8 \mathrm{~kg} \mathrm{Nha}^{-1}$ (Figure 5). Thus, final cumulative extractions from MG-treated forest and pasture soils, though distinct from each other (129 compared to $211 \mathrm{~kg} \mathrm{Nha}^{-1}$ ), were not appreciably different from cumulative extractions with water (Figure 6). In contrast, the PGG treatment reduced soluble- $\mathrm{N}$ in treatment supernatants, the cool water rinse, and the final hot water incubation with reductions of hot water soluble-N equivalent to 14 and $53 \mathrm{~kg} \mathrm{~N} \mathrm{ha}^{-1}$ from forest and pasture (Figures 4 and 5, Table 3). All together, PGG reduced soluble- $\mathrm{N}$ from the forest soil by $71 \mathrm{mg} \mathrm{kg}^{-1}$ soil or $35 \mathrm{~kg} \mathrm{ha}^{-1}$ and from pasture soil by $170 \mathrm{mg} \mathrm{kg}^{-1}$ soil or $97 \mathrm{~kg} \mathrm{ha}^{-1}$.

Reductions in $\mathrm{N}$ availability by condensed tannins are attributed to formation of protein-tannin complexes with soil protein that are more recalcitrant than those formed with hydrolyzable tannins in part because they are less available to microorganisms as substrate $[10,50-52]$. However, the strong reductions in solubility of labile soil-N, observed for TA and PGG, suggest hydrolyzable tannins may play a more prominent role in abiotic immobilization of organic soil-N than previously thought. A study by Hagerman et al. [45] concluded PGG, a nonpolar tannin (Table 2), precipitated with bovine serum albumin (BSA) by forming a hydrophobic coat around the protein while the more polar, SOR, formed hydrogen-bond cross-links between BSA molecules.

In addition to precipitation, polymerization resulting from condensation reactions between phenolic and aminocontaining compounds in solution can occur. Oxidation of phenolics, forming semiquinones and quinones, can be carried out biotically by the polyphenol oxidase enzymes and/or abiotically by redox reactions with manganese and iron oxides $[53,54]$. When PGG is oxidized, it forms covalently linked complexes with protein [55].

Additions of some tannins/phenolics to the soil resulted in the dissolution of $\mathrm{Mn}$ oxides, evinced by increased $\mathrm{Mn}$ content in the supernatant [56]. Mobilization of other soil metals such as $\mathrm{Fe}, \mathrm{Al}$ and $\mathrm{Si}$ by tannins has also been observed $[29,57]$. During the dissolution of Mn oxides, the Mn may be reduced from insoluble $\mathrm{Mn}$ (III and IV) to soluble $\mathrm{Mn}$ (II), which is available for plants. Phenolic compounds could be oxidized, forming quinones and semiquinones, the latter a highly reactive radical that readily self-polymerizes or copolymerizes with other compounds [58]. Tannic acid, gallic acid, and other polyhydroxy phenols with $\mathrm{OH}-\mathrm{OH}$ in the orthopositions are known to be highly effective in the dissolution of $\mathrm{Mn}$ in soils with high Mn oxides content [59] or in synthetic Mn oxide [60]. Thus, the lower soluble-N extracted with PGG, GA, or TA solutions compared to other compounds might be due in part to redox reactions with soil $\mathrm{Mn}$ together with oxidation of these organic compounds into quinones or semiquinones and formation of "humiclike" polymers with amino-containing compounds that were retained in the soil matrix.

The significant interactions between treatment and land use, observed for $\Delta$ Sol-N, indicated the effects of phenolic plant inputs were of greater consequence in land managed as pasture than the surrounding woodlands (Figures 4-6). Variations in soil microbial community composition, related to land use, have been suggested to explain variations in the mineralization of tannin-protein complexes [13]; however this study and our related work [33] also suggest land use can affect the initial reactions between tannins and soil.

The effects of tannins on soil organic matter and nutrient cycling have important implications for livestock production in mixed systems such as silvopastures that include a mixture of forages together with browse and overstory tree species [61-64]. Appalachian silvopasture soil typically differs from 
the surrounding unmanaged woodland because it is limed to increase soil $\mathrm{pH}$, receives additional $\mathrm{N}$-inputs from fertilizers and manure, and can develop greater bulk density due to compaction by livestock (Table 1). In addition, transitioning from either forest or pasture to a silvopastoral mixed stand, containing both forages and overstory, may affect soil nitrogen pools by redistributing the patterns of nutrients in soils and biomass. Decreases in soil $\mathrm{C}$ and $\mathrm{N}$ have been associated with afforestation, especially in the case of pines [65]. Two years after conversion from a mixed hardwood woodland, Staley et al. [66] reported losses of organic-C and -N from West Virginia silvopasture soil of 17 and 9\%, respectively, which they attributed to litter decomposition.

Along with their effects on soil organic matter and the availability of nitrogen, tannins and related phenolic compounds can interact with important metals in soil, such as $\mathrm{Ca}, \mathrm{Mn}, \mathrm{Al}$, and $\mathrm{Fe}$, probably through chelation and oxidation/reduction reactions $[67,68]$. Interactions between metals and phenolic compounds may inhibit or promote plant growth in forest soil. For example, tannic acid has been reported to reduce the rate of root growth by itself but has also been shown to mitigate the toxic effects of $\mathrm{Al}$ on roots [69] and in soil $[10,26]$. In addition tannins affect nutrient value of forages (e.g., $[70,71]$ ) and animal health [72, 73]. Thus, tannins can link plant productivity, ruminant physiology, pathogen survival, and environmental quality in agroecosystems.

The results of this study indicate hydrolyzable tannins like PGG can quickly reduce the solubility of labile soil-N more than condensed tannins like SOR and suggest tannin effects will vary with land management. However information about short-term reactions that incorporate tannin- $\mathrm{C}$ onto the soil matrix and immobilize soil-N must be considered together with their potential for chemical and biological degradation [33]. Further work is required to determine the persistence of tannin effects as they are degraded by soil microorganisms or other soil biota [74], physically lost by leaching, or chemically oxidized after interacting with soil metals $[67,68]$.

Tannins and other phenolic compounds affect a number of important biological, chemical, and physical processes in plants animals and soil. Studies such as this improve our understanding of the effects of natural phenolic inputs on soil organic matter and nutrient cycling and will ultimately lead to new management strategies. Future research on tannins and other plant polyphenolics in soil ecosystems should be focused towards understanding their effects on plant productivity and soil function. Functional definitions linking specific tannin chemistry to soil processes are required that can also serve as a rationale for comparing tannins. Research remains hampered by a lack of standardized methods that simplify the extraction, identification, and quantification of tannins from plants and soil and that can be adapted to field measurements. Experimental field work will remain difficult until suitable model tannins can be identified that are available in reasonable quantities and expense.

Because they are chemically and biologically active, tannins appear to have the potential to be used to improve nitrogen retention by soils but additional work is needed to determine how long their effects can last and whether the retained $\mathrm{N}$ is readily available to crop or forage plants. The effects of tannins on nutrient cycling will likely be influenced by specific tannin chemistry $[13,75,76]$, vary with tannin concentrations, and the quantity and quality of soil $\mathrm{N}$ [77].

\section{Disclaimer}

USDA is an equal opportunity provider and employer. Mention of trade names or commercial products in this publication is solely for the purpose of providing specific information and does not imply recommendation or endorsement by the US Department of Agriculture.

\section{Acknowledgments}

The authors thank J. Harrah and T. Robertson for excellent analytical assistance. This work is dedicated to P. J. A. Halvorson.

\section{References}

[1] S. Hättenschwiler and P. M. Vitousek, "The role of polyphenols in terrestrial ecosystem nutrient cycling," Trends in Ecology and Evolution, vol. 15, no. 6, pp. 238-242, 2000.

[2] T. E. C. Kraus, R. A. Dahlgren, and R. J. Zasoski, "Tannins in nutrient dynamics of forest ecosystems-a review," Plant and Soil, vol. 256, no. 1, pp. 41-66, 2003.

[3] J. D. Horner, J. R. Gosz, and R. G. Cates, "The role of carbonbased plant secondary metabolites in decomposition in terrestrial ecosystems," American Naturalist, vol. 132, no. 6, pp. 869$883,1988$.

[4] M. von Lützow, I. Kögel-Knabner, K. Ekschmitt et al., "Stabilization of organic matter in temperate soils: mechanisms and their relevance under different soil conditions-a review," European Journal of Soil Science, vol. 57, no. 4, pp. 426-445, 2006.

[5] C. B. Coulson, R. I. Davies, and D. A. Lewis, "Polyphenols in plant, humus and soil. 1. Polyphenols of leaves, litter and superficial humus from mull and mor sites," Journal of Soil Science, vol. 11, no. 1, pp. 20-29, 1960.

[6] W. R. C. Handley, "Further evidence for the importance of residual leaf protein complexes in litter decomposition and the supply of nitrogen for plant growth," Plant and Soil, vol. 15, no. 1, pp. 37-73, 1961.

[7] J. Lewis and R. Starkey, "Vegetable tannins, their decomposition and effects of decomposition of some organic compounds," Soil Science, vol. 106, pp. 241-247, 1968.

[8] J. Basaraba, "Influence of vegetable tannins on nitrification in soil," Plant and Soil, vol. 21, no. 1, pp. 8-16, 1964.

[9] J. Basaraba and R. L. Starkey, "Effect of plant tannins on decomposition of organic substances," Soil Science, vol. 101, no. 1, pp. 17-23, 1966.

[10] P. Kraal, K. G. J. Nierop, J. Kaal, and A. Tietema, “Carbon respiration and nitrogen dynamics in Corsican pine litter amended with aluminium and tannins," Soil Biology and Biochemistry, vol. 41, no. 11, pp. 2318-2327, 2009.

[11] G. D. Joanisse, R. L. Bradley, C. M. Preston, and G. D. Bending, "Sequestration of soil nitrogen as tannin-protein complexes may improve the competitive ability of sheep laurel (Kalmia angustifolia) relative to black spruce (Picea mariana)," New Phytologist, vol. 181, no. 1, pp. 187-198, 2009. 
[12] T. E. C. Kraus, R. J. Zasoski, R. A. Dahlgren, W. R. Horwath, and C. M. Preston, "Carbon and nitrogen dynamics in a forest soil amended with purified tannins from different plant species," Soil Biology and Biochemistry, vol. 36, no. 2, pp. 309-321, 2004.

[13] R. Mutabaruka, K. Hairiah, and G. Cadisch, "Microbial degradation of hydrolysable and condensed tannin polyphenol-protein complexes in soils from different land-use histories," Soil Biology and Biochemistry, vol. 39, no. 7, pp. 1479-1492, 2007.

[14] K. Sivapalan, V. Fernando, and M. W. Thenabadu, "Humified phenol-rich plant residues and soil urease activity," Plant and Soil, vol. 70, no. 1, pp. 143-146, 1983.

[15] K. Sivapalan, V. Fernando, and M. W. Thenabadu, "N-mineralization in polyphenol-rich plant residues and their effect on nitrification of applied ammonium sulphate," Soil Biology and Biochemistry, vol. 17, no. 4, pp. 547-551, 1985.

[16] A. Scalbert, "Antimicrobial properties of tannins," Phytochemistry, vol. 30, no. 12, pp. 3875-3883, 1991.

[17] F. A. Einhellig, "Mode of allelochemical action of phenolic compounds," in Allelopathy: Chemistry and Mode of Action, $\mathrm{F}$. A. Macías et al., Ed., pp. 217-238, CRC Press, Boca Raton, Fla, USA, 2004.

[18] T. K. Bhat, B. Singh, and O. P. Sharma, "Microbial degradation of tannins-a current perspective," Biodegradation, vol. 9, no. 5, pp. 343-357, 1998.

[19] J. P. Schimel, R. G. Cates, and R. Ruess, "The role of balsam poplar secondary chemicals in controlling soil nutrient dynamics through succession in the Alaskan taiga," Biogeochemistry, vol. 42, no. 1-2, pp. 221-234, 1998.

[20] R. E. Benoit and R. L. Starkey, "Enzyme inactivation as a factor in the inhibition of decomposition of organic matter by tannins," Soil Science, vol. 105, no. 4, pp. 203-208, 1968.

[21] G. D. Joanisse, R. L. Bradley, C. M. Preston, and A. D. Munson, "Soil enzyme inhibition by condensed litter tannins may drive ecosystem structure and processes: the case of Kalmia angustifolia," New Phytologist, vol. 175, no. 3, pp. 535-546, 2007.

[22] M. C. Rillig, B. A. Caldwell, H. A. B. Wösten, and P. Sollins, "Role of proteins in soil carbon and nitrogen storage: controls on persistence," Biogeochemistry, vol. 85, no. 1, pp. 25-44, 2007.

[23] B. Adamczyk, S. Adamczyk, A. Smolander, and V. Kitunen, "Tannic acid and Norway spruce condensed tannins can precipitate various organic nitrogen compounds," Soil Biology and Biochemistry, vol. 43, no. 3, pp. 628-637, 2011.

[24] E. Castells, "Indirect effects of phenolics on plant performance by altering nitrogen cycling: another mechanism of plantplant negative interactions," in Allelopathy in Sustainable Agriculture and Forestry, R. S. Zeng, A. U. Mallik, and S. M. Luo, Eds., pp. 137-156, Springer, New York., NY, USA, 2008.

[25] N. Wurzburger and R. L. Hendrick, "Plant litter chemistry and mycorrhizal roots promote a nitrogen feedback in a temperate forest," Journal of Ecology, vol. 97, no. 3, pp. 528-536, 2009.

[26] R. R. Northup, R. A. Dahlgren, and J. G. McColl, "Polyphenols as regulators of plant-litter-soil interactions in northern California's pygmy forest: a positive feedback?" Biogeochemistry, vol. 42, no. 1-2, pp. 189-220, 1998.

[27] G. D. Bending and D. J. Read, "Effects of the soluble polyphenol tannic acid on the activities of ericoid and ectomycorrhizal fungi," Soil Biology and Biochemistry, vol. 28, no. 12, pp. 1595 1602, 1996.
[28] G. D. Bending and D. J. Read, "Nitrogen mobilization from protein-polyphenol complex by ericoid and ectomycorrhizal fungi," Soil Biology and Biochemistry, vol. 28, no. 12, pp. 16031612, 1996.

[29] J. Kaal, K. G. J. Nierop, and J. M. Verstraten, "Retention of tannic acid and condensed tannin by Fe-oxide-coated quartz sand," Journal of Colloid and Interface Science, vol. 287, no. 1, pp. 72-79, 2005.

[30] S. El Azhar, R. Verhe, M. Proot, P. Sandra, and W. Verstraete, "Binding of nitrite-N on polyphenols during nitrification," Plant and Soil, vol. 94, no. 3, pp. 369-382, 1986.

[31] S. El Azhar, J. Vandenabeele, and W. Verstraete, "Nitrification and organic nitrogen formation in soils," Plant and Soil, vol. 94, no. 3, pp. 383-399, 1986.

[32] R. D. Fitzhugh, G. M. Lovett, and R. T. Venterea, "Biotic and abiotic immobilization of ammonium, nitrite, and nitrate in soils developed under different tree species in the Catskill Mountains, New York, USA," Global Change Biology, vol. 9, no. 11, pp. 1591-1601, 2003.

[33] J. J. Halvorson, J. M. Gonzalez, A. E. Hagerman, and J. L. Smith, "Sorption of tannin and related phenolic compounds and effects on soluble-N in soil," Soil Biology and Biochemistry, vol. 41, no. 9, pp. 2002-2010, 2009.

[34] J. J. Halvorson, J. M. Gonzalez, and A. E. Hagerman, "Repeated applications of tannins and related phenolic compounds are retained by soil and affect cation exchange capacity," Soil Biology and Biochemistry, vol. 43, no. 6, pp. 1139-1147, 2011.

[35] J. J. Halvorson and J. M. Gonzalez, "Tannic acid reduces recovery of water-soluble carbon and nitrogen from soil and affects the composition of Bradford-reactive soil protein," Soil Biology and Biochemistry, vol. 40, no. 1, pp. 186-197, 2008.

[36] J. J. Halvorson and J. M. Gonzalez, "Bradford reactive soil protein in Appalachian soils: distribution and response to incubation, extraction reagent and tannins," Plant and Soil, vol. 286, no. 1-2, pp. 339-356, 2006.

[37] D. W. Nelson and L. E. Sommers, "Total carbon, organic carbon and organic matter," in Methods of Soil Analysis Part 3: Chemical Methods, D. L. Sparks et al., Ed., Soil Science Society of America Books Series No. 5, pp. 961-1010, Soil Science Society of America, Inc., Madison, Wis, USA, 1996.

[38] H. Ciesielski and T. Sterckeman, "Determination of cation exchange capacity and exchangeable cations in soils by means of cobalt hexamine trichloride. Effects of experimental conditions," Agronomie, vol. 17, no. 1, pp. 1-7, 1997.

[39] H. Ciesielski and T. Sterckeman, "A comparison between three methods for the determination of cation exchange capacity and exchangeable cations in soils," Agronomie, vol. 17, no. 1, pp. 9-16, 1997.

[40] ISO 23470:2007, "Soil quality-determination of effective cation exchange capacity (CEC) and exchangeable cations using a hexamminecobalt trichloride solution," ISO/TC 190, Soil quality Subcommitte SC3, Chemical methods and soil characteristics, 2007.

[41] A. Ghani, M. Dexter, and K. W. Perrott, "Hot-water extractable carbon in soils: a sensitive measurement for determining impacts of fertilisation, grazing and cultivation," Soil Biology and Biochemistry, vol. 35, no. 9, pp. 1231-1243, 2003.

[42] D. Curtin, C. E. Wright, M. H. Beare, and F. M. McCallum, "Hot water-extractable nitrogen as an indicator of soil nitrogen availability," Soil Science Society of America Journal, vol. 70, no. 5, pp. 1512-1521, 2006. 
[43] C. Gallet and P. Lebreton, "Evolution of phenolic patterns in plants and associated litters and humus of a mountain forest ecosystem," Soil Biology and Biochemistry, vol. 27, no. 2, pp. 157-165, 1995.

[44] A. E. Hagerman, The Tannin Handbook, Miami University, Oxford, Ohio, USA, 2002.

[45] A. E. Hagerman, M. E. Rice, and N. T. Ritchard, "Mechanisms of Protein Precipitation for Two Tannins, Pentagalloyl Glucose and Epicatechin16 $(4 \rightarrow 8)$ Catechin (Procyanidin)," Journal of Agricultural and Food Chemistry, vol. 46, no. 7, pp. 2590-2595, 1998.

[46] Z. Lu, G. Nie, P. S. Belton, H. Tang, and B. Zhao, "Structureactivity relationship analysis of antioxidant ability and neuroprotective effect of gallic acid derivatives," Neurochemistry International, vol. 48, no. 4, pp. 263-274, 2006.

[47] R. C. Littell, G. A. Milliken, W. W. Stroup, and R. D. Wolfinger, SAS System for Mixed Models, SAS Institute Inc., Cary, NC, USA, 1996.

[48] SAS, "SAS OnlineDoc, Version 8," SAS Institute, Inc., Cary, NC, USA, 1999.

[49] P. Leinweber, H. R. Schulten, and M. Korschens, "Hot water extracted organic matter: chemical composition and temporal variations in a long-term field experiment," Biology and Fertility of Soils, vol. 20, no. 1, pp. 17-23, 1995.

[50] R. L. Bradley, B. D. Titus, and C. P. Preston, "Changes to mineral $\mathrm{N}$ cycling and microbial communities in black spruce humus after additions of $\left(\mathrm{NH}_{4}\right)_{2} \mathrm{SO}_{4}$ and condensed tannins extracted from Kalmia angustifolia and balsam fir," Soil Biology and Biochemistry, vol. 32, no. 8-9, pp. 1227-1240, 2000.

[51] K. G. J. Nierop and J. M. Verstraten, "Fate of tannins in Corsican pine litter," Journal of Chemical Ecology, vol. 32, no. 12, pp. 2709-2719, 2006.

[52] B. Adamczyk, V. Kitunen, and A. Smolander, "Polyphenol oxidase, tannase and proteolytic activity in relation to tannin concentration in the soil organic horizon under silver birch and Norway spruce," Soil Biology and Biochemistry, vol. 41, no. 10, pp. 2085-2093, 2009.

[53] F. J. Stevenson, Humus Chemistry: Genesis, Composition, Reactions, John Wiley \& Sons, 2nd edition, 1994.

[54] P. J. Hernes, R. Benner, G. L. Cowie, M. A. Goi, B. A. Bergamaschi, and J. I. Hedges, "Tannin diagenesis in mangrove leaves from a tropical estuary: a novel molecular approach," Geochimica et Cosmochimica Acta, vol. 65, no. 18, pp. 31093122, 2001.

[55] Y. Chen and A. E. Hagerman, "Reaction $\mathrm{pH}$ and protein affect the oxidation products of $\beta$-pentagalloyl glucose," Free Radical Research, vol. 39, no. 2, pp. 117-124, 2005.

[56] J. J. Halvorson, J. M. Gonzalez, and A. E. Hagerman, "Effects of tannins on soil carbon, cation exchange capacity, and metal solubility," in Proceedings of the 94th Ecological Society of America Annual Meeting, Albuquerque, NM, USA, August 2009.

[57] J. Kaal, K. G. J. Nierop, and J. M. Verstraten, "Interactions between tannins and goethite- or ferrihydrite-coated quartz sand: influence of $\mathrm{pH}$ and evaporation," Geoderma, vol. 139, no. 3-4, pp. 379-387, 2007.

[58] R. Liu, "Comment on "surface complexation of catechol to metal oxides: an ATR-FTIR, adsorption, and dissolution study"', Environmental Science and Technology, vol. 44, no. 16, pp. 6517-6518, 2010.

[59] N. V. Hue, S. Vega, and J. A. Silva, "Manganese toxicity in a Hawaiian Oxisol affected by soil $\mathrm{pH}$ and organic amendments," Soil Science Society of America Journal, vol. 65, no. 1, pp. 153-160, 2001.
[60] A. T. Stone and J. J. Morgan, "Reduction and dissolution of manganese(III) and manganese(IV) oxides by organics: 2 . Survey of the reactivity of organics," Environmental Science and Technology, vol. 18, no. 8, pp. 617-624, 1984.

[61] R. P. Udawatta and L. D. Godsey, "Agroforestry comes of age: putting science into practice," Agroforestry Systems, vol. 79, no. 1, pp. 1-4, 2010.

[62] C. M. Feldhake, J. P. S. Neel, and D. P. Belesky, "Establishment and production from thinned mature deciduous-forest silvopastures in Appalachia," Agroforestry Systems, vol. 79, no. 1, pp. 31-37, 2010.

[63] J. P. S. Neel, C. M. Feldhake, and D. P. Belesky, "Influence of solar radiation on the productivity and nutritive value of herbage of cool-season species of an understorey sward in a mature conifer woodland," Grass and Forage Science, vol. 63, no. 1, pp. 38-47, 2008.

[64] V. D. Nair, S. G. Haile, G. A. Michel, and P. K. R. Nair, "Environmental quality improvement of agricultural lands through silvopasture in Southeastern United States," Scientia Agricola, vol. 64, no. 5, pp. 513-519, 2007.

[65] S. T. Berthrong, E. G. Jobbágy, and R. B. Jackson, "A global meta-analysis of soil exchangeable cations, $\mathrm{pH}$, carbon, and nitrogen with afforestation," Ecological Applications, vol. 19, no. 8, pp. 2228-2241, 2009.

[66] T. E. Staley, J. M. Gonzalez, and J. P. S. Neel, "Conversion of deciduous forest to silvopasture produces soil properties indicative of rapid transition to improved pasture," Agroforestry Systems, vol. 74, no. 3, pp. 267-277, 2008.

[67] E. H. Majcher, J. Chorover, J. M. Bollag, and P. M. Huang, "Evolution of $\mathrm{CO}_{2}$ during birnessite-induced oxidation of ${ }^{14} \mathrm{C}$ labeled catechol," Soil Science Society of America Journal, vol. 64, no. 1, pp. 157-163, 2000.

[68] H. M. Appel, "Phenolics in ecological interactions: the importance of oxidation," Journal of Chemical Ecology, vol. 19, no. 7, pp. 1521-1552, 1993.

[69] T. B. Kinraide and A. E. Hagermann, "Interactive intoxicating and ameliorating effects of tannic acid, aluminum $\left(\mathrm{Al}^{3+}\right)$, copper $\left(\mathrm{Cu}^{2+}\right)$, and selenate $\left(\mathrm{SeO}_{4}^{2-}\right)$ in wheat roots: a descriptive and mathematical assessment," Physiologia plantarum, vol. 139, no. 1, pp. 68-79, 2010.

[70] T. N. Barry and W. C. McNabb, "The implications of condensed tannins on the nutritive value of temperate forages fed to ruminants," British Journal of Nutrition, vol. 81, no. 4, pp. 263-272, 1999.

[71] B. R. Min, T. N. Barry, G. T. Attwood, and W. C. McNabb, "The effect of condensed tannins on the nutrition and health of ruminants fed fresh temperate forages: a review," Animal Feed Science and Technology, vol. 106, no. 1-4, pp. 3-19, 2003.

[72] H. Hoste, F. Jackson, S. Athanasiadou, S. M. Thamsborg, and S. O. Hoskin, "The effects of tannin-rich plants on parasitic nematodes in ruminants," Trends in Parasitology, vol. 22, no. 6, pp. 253-261, 2006.

[73] I. Mueller-Harvey, "Unravelling the conundrum of tannins in animal nutrition and health," Journal of the Science of Food and Agriculture, vol. 86, no. 13, pp. 2010-2037, 2006.

[74] M. Coulis, S. Hättenschwiler, S. Rapior, and S. Coq, "The fate of condensed tannins during litter consumption by soil animals," Soil Biology and Biochemistry, vol. 41, no. 12, pp. 25732578, 2009.

[75] T. E. C. Kraus, Z. Yu, C. M. Preston, R. A. Dahlgren, and R. J. Zasoski, "Linking chemical reactivity and protein precipitation to structural characteristics of foliar tannins," Journal of Chemical Ecology, vol. 29, no. 3, pp. 703-730, 2003. 
[76] S. Coq, J. M. Souquet, E. Meudec, V. Cheynier, and S. Hättenschwiler, "Interspecific variation in leaf litter tannins drives decomposition in a tropical rain forest of French Guiana," Ecology, vol. 91, no. 7, pp. 2080-2091, 2010.

[77] J. M. Talbot and A. C. Finzi, "Differential effects of sugar maple, red oak, and hemlock tannins on carbon and nitrogen cycling in temperate forest soils," Oecologia, vol. 155, no. 3, pp. 583-592, 2008. 


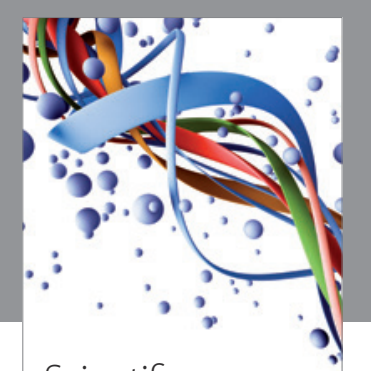

Scientifica
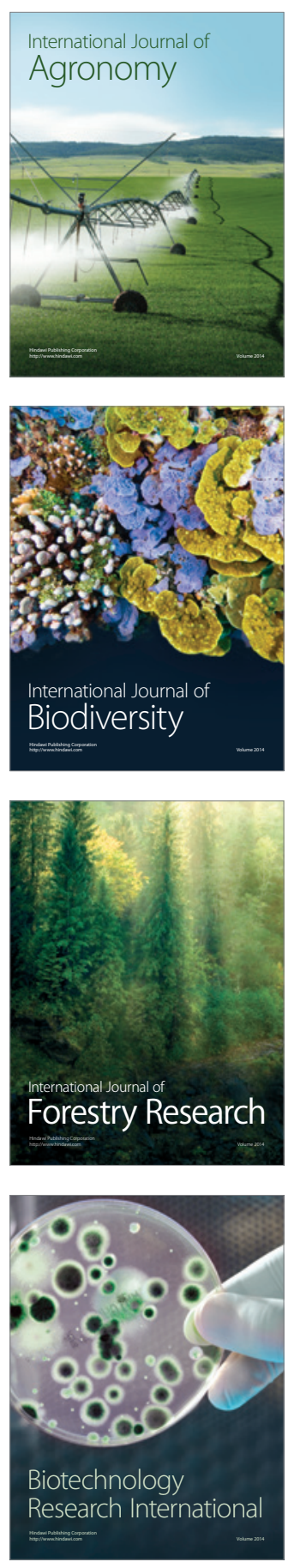
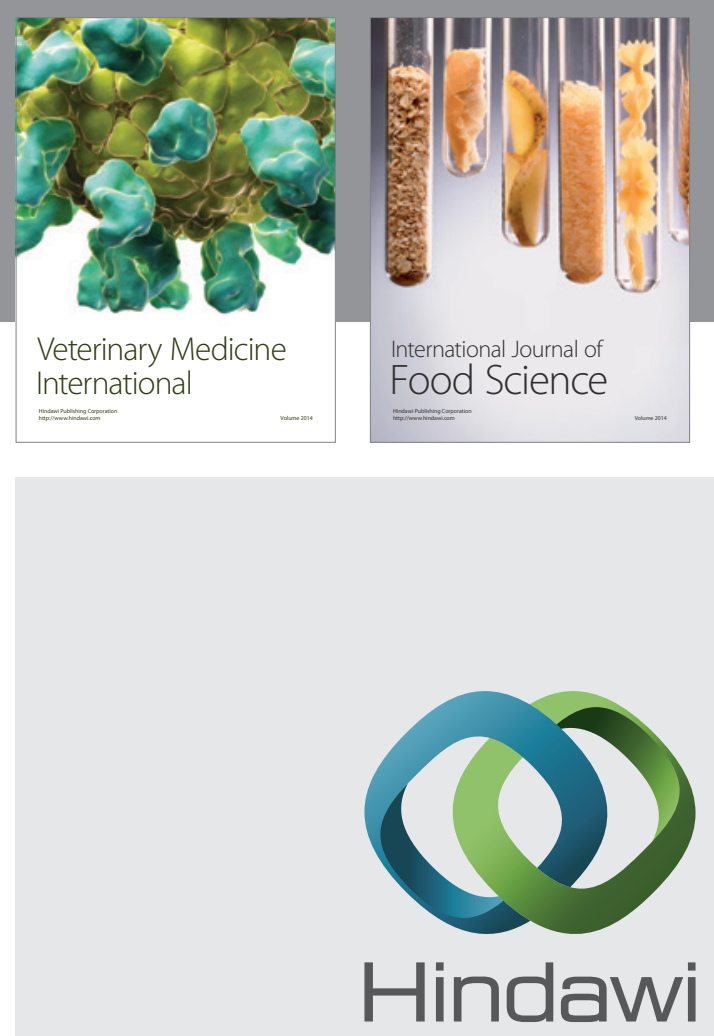

Submit your manuscripts at

http://www.hindawi.com
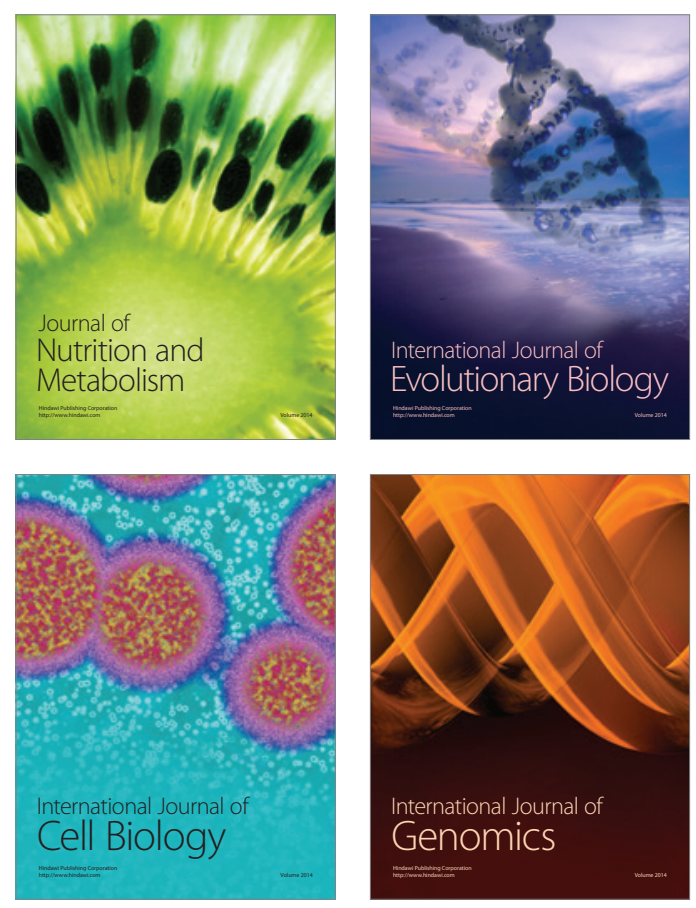
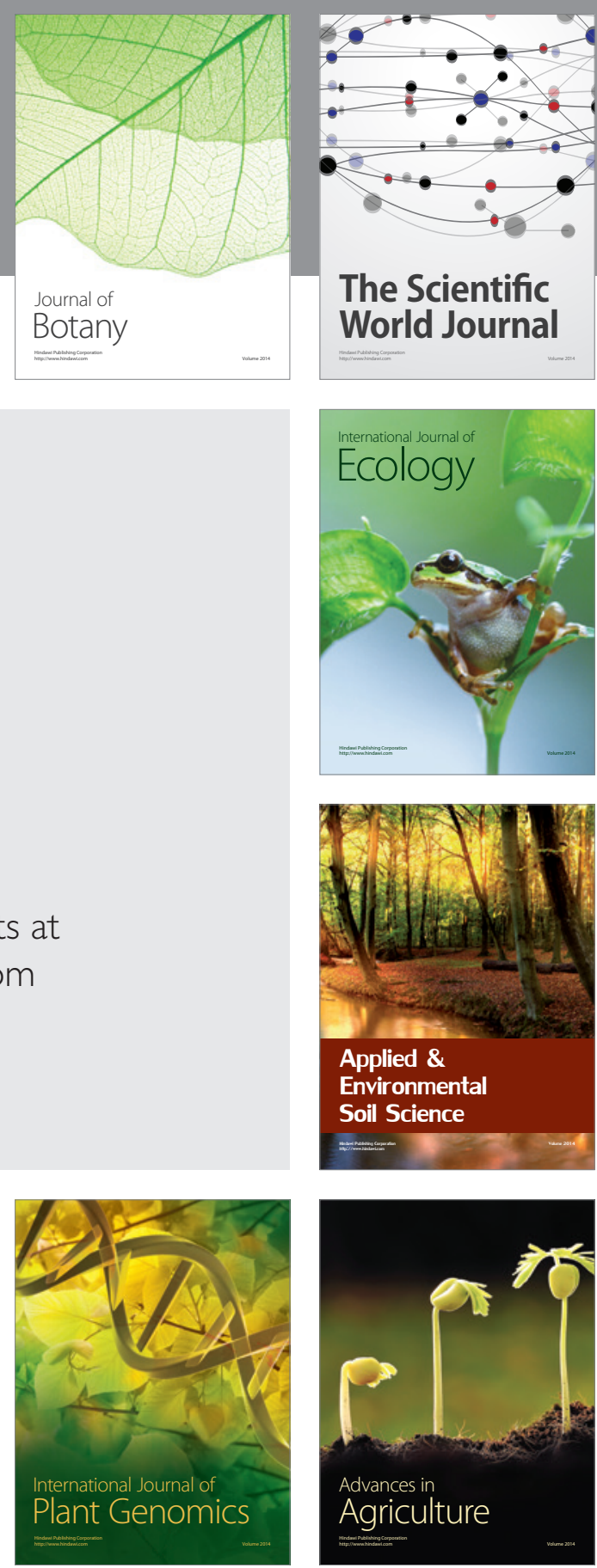

The Scientific World Journal
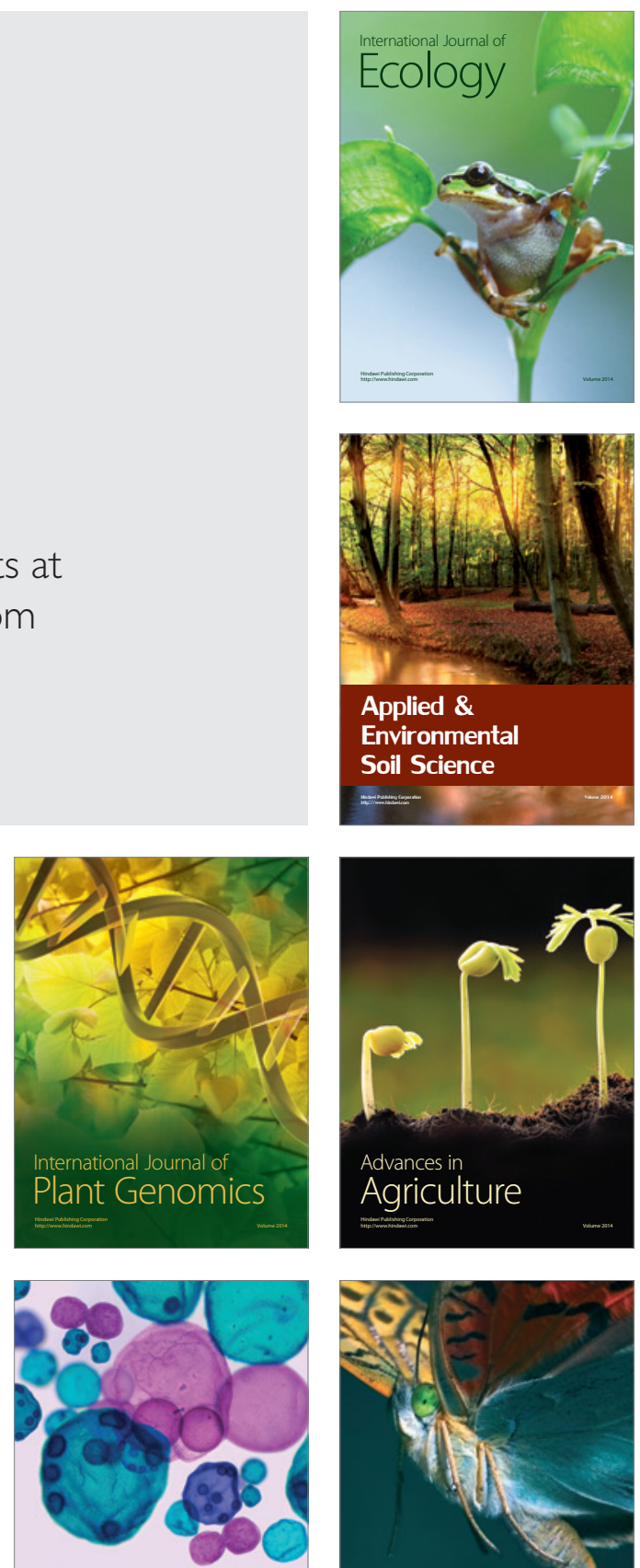

International Journal of Microbiology

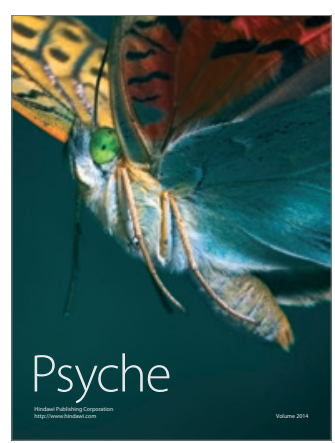

